\title{
SIR JAMES MACKENZIE: THE BURNLEY YEARS
}

\section{by}

\author{
A. E. WALES AND J. SHAFAR
}

THE Industrial Revolution transformed Burnley from a country town with a population of some 5,000 whose main occupations were sheep farming and the hand loom weaving of woollen cloth to one of almost 100,000 by the beginning of the present century. Factories, warehouses, foundries, workshops and coal mines had attracted the new labour force and the rapid influx was attended with appalling housing conditions and grossly inadequate sanitary arrangements. The increase of paupers and casuals had rendered the existing workhouse accommodation inadequate and necessitated new premises in 1870 to house 500 inmates with wards for 300 vagrants; a new infirmary was attached and this is now the Burnley General Hospital.

As Mackenzie was one of the leading figures pressing for the erection of a new hospital to serve the town, the story of the building of Victoria Hospital is relevant. Burnley possessed no permanent hospital until the erection of the Victoria, the relief of patients being supplied by a Dispensary founded in 1850 through the work of Archdeacon Master. The Dispensary was situated in a house in Prospect Terrace and was in operation until it closed for lack of funds in 1854. At infrequent intervals and chiefly through the agitation of various ministers of religion, meetings were called in support of the erection of a hospital but it was not until 1882 and through the suggestion of Dr. Brown that a committee, consisting of the Rev. R. H. Giles, Dr. Mackenzie and Messrs. Grant, Grey, Hoghton and Ward, succeeded in enlisting the financial interest of many wealthy men in the town and district. Both Dr. Briggs and Dr. Brown were very active in these preliminary negotiations and by May 1884 nearly $£ 13,000$ had been raised. Building started that year on three acres in the Burnley Lane District and the Victoria Hospital was erected on the 'circular ward principle, the latest and most approved system'. It was opened in 1886 by H.R.H. Prince Albert Victor 'amidst a burst of enthusiasm and loyalty never equalled in Burnley' as one report puts it. Not only was subscription to the building fund something of a 'status symbol' for the rich mill owners of the town, but over $£ 4,000$ was raised by mill and workshop collections. Mackenzie became a consultant physician to the hospital and also occasionally acted in a surgical capacity.

Mackenzie arrived into the grim industrial atmosphere of Burnley in 1879 when he was about 26 years old, taking up residence at 68 Bank Parade, the home of the senior partner, Dr. W. Briggs. His school days had been undistinguished. Subsequent employment in a pharmacist's establishment had aroused in him the desire to practise medicine. His choice of practice proved doubly fortunate for him; the diagnostic skill of Briggs-who was a graduate of University College Hospital and a gold medallistprovided an inspiration to him and it was the lack of satisfactory information in the existing medical literature which set him on the course of accumulating data in order to arrive at the natural history of symptoms and the evaluation of hitherto wrongly 


\section{A. E. Wales and J. Shafar}

interpreted physical findings; from Dr. Brown he received unfailing encouragement and support in the frequent periods of personal doubt.

Recognition came slowly for Mackenzie and open acclaim had to wait until he had left Burnley, but towards the end of his Burnley period, some discerning physicians and those mostly from the Continent, the U.S.A. and Canada, recognized the importance of his work. Not only was he using his polygraph extensively between 1883 and 1890, but during those years he spent many hours with Ernest Evans, the Head of the Natural History Department of the local Technical Institute dissecting animal hearts in the Institute's laboratories. On more than one occasion too he gave lectures to the members of the Literary and Philosophical Society on the action of the heart, and even introduced patients so that he could illustrate his lectures with tracings from his polygraph to those large lay audiences. During the 1890 s he took every opportunity to interest his medical colleagues in his findings and to have his methods adopted in general practice. He made a number of visits around 1890-1900 to Manchester giving lectures and demonstrations with all the enthusiasm of the pioneer, but these would be received in silence; there would be neither questions nor discussions afterwards and in a short time, Mackenzie would be left alone in the lecture room surrounded by yards and yards of tracings, with nothing more to do than to pack up his polygraph and films and retrace his steps to Burnley. Except for Graham Steell, one looks in vain in the Manchester area, for any recognition of the importance of his work and only one young hospital doctor in the Liverpool area, John Hay, realized the clinical value of his teachings.

But there were foreign and colonial medical men who were alive to the fundamental importance of Mackenzie's work. About 1900 the Dutch physician Wenckebach, whose work on the arrythmias ranks with that of Mackenzie, visited Burnley and later paid tribute to Mackenzie's pioneering work, although it is said that he subsequently showed a streak of jealousy. Mackenzie however, thought highly of Wenckebach's contributions and in 1903, persuaded his colleague Dr. T. Snowball to translate Wenckebach's monograph on the arrythmias from the German. In 1905, Osler, soon after his appointment as Regius Professor at Oxford, visited Mackenzie in Burnley and Mackenzie never forgot the compliment of being acclaimed by a man of Osler's stature in medicine. Osler continued to bestow great praise on Mackenzie's work, praise which he repeated at a great Congress of American Physicians at Washington in 1907. In 1906, Mackenzie attended the meeting of the British Medical Association in Toronto, largely at Dr. Brown's instigation. He came and went as a humble general practitioner, unnoticed by the leaders of the British contingent, which included Allbutt, Broadbent and Gibson of Edinburgh, all of whom were later to become his friends. But on this occasion, Mackenzie read two papers, one during a symposium on blood pressure and the other during a symposium on heart block, during which he reinforced his views by producing the simultaneously traced records of the jugular and radial pulses. Mackenzie at that time was $\mathbf{5 2}$ years old, tall and powerfully built and a comparatively unknown general practitioner. He spoke as usual with great enthusiasm about his discoveries and this time he made a lasting impression. This was the very first occasion on which he made his work clear to a large and interested audience, although it is reported that some physicians afterwards 


\section{Sir James Mackenzie: The Burnley Years}

always referred to him as 'Heart Block Mackenzie'. Dr. J. H. Pratt of Boston became an enthusiastic convert at this meeting and, sensing the importance of his contribution, invited Mackenzie to his home where he arranged an evening meeting of medical men to whom Mackenzie demonstrated his methods and discussed his findings. It was Pratt too, who introduced him to Professor W. T. Porter of Harvard Medical School. Mackenzie hoped that Porter, who owned a small instrumentmaking business, would manufacture and sell the new improved model of his polygraph, but this deal did not materialize.

What did materialize from this successful trip, however, was that increasing numbers of medical men from Canada and the U.S.A. visited Mackenzie's home in Burnley during the next two years. Amongst others Dr. G. W. Ross came from Toronto and stayed at Bank Parade to learn Mackenzie's methods since he openly admitted that he could not obtain the knowledge of certain aspects of cardiac diseases from any other source. Dr. Grosh came from Toledo, and Dr. A. R. Cushny from America.

But in spite of this widening circle of recognition, there exists a letter written by Mackenzie to Pratt of Boston at this time which tells of his lecturing to the newly formed Association of Physicians in London on the significance of continuous irregular heart beats and on the causes of heart failure (a meeting incidentally attended by Osler) in which the audience failed to appreciate his facts and remained unconvinced.

Apart from this intense research work into the many aspects of heart disease, what type of life did Mackenzie lead during those 28 years in Burnley before he determined, perhaps on Osler's advice, to proffer his new knowledge and views to the challenge of the London medical world? The answer to this question must be found not only in his non-medical activities but also in the more intimate relationship he enjoyed with his partners, his family, his contemporaries in the medical world of Burnley and in the wider circle of patients and friends in every walk of life in an industrial town.

In 1887 at the age of 34, Mackenzie met and fell in love with Frances Bellamy Jackson, who had come to Burnley to be governess to the Hargreaves children, whose father was the senior director of a large colliery concern. They were married in that year and lived at 64 Bank Parade. Dr. and Mrs. Mackenzie had a family of two children, both girls. Dorothy was born in 1888. Although crippled by poliomyelitis from an early age, she became an artist of merit and a great favourite with her father. Jean, born in 1893, was, of the two, a more vivacious type of girl. Because she was unhappy as a boarder at Skipton Grammar School she was transferred to Burntey Grammar School, then a mixed school. After showing great promise as a student at Queen's College, London, she died in 1909 of meningitis.

So bald a recital of misfortune may give the mistaken impression that Mackenzie's married life was unhappy. Throughout their period in Burnley, the Mackenzies lived a close-knit and ordered family life, whose daily round was dominated by the father, as was usual in Victorian times. Mrs. Mackenzie was a cultured woman completely devoted to her husband and family, and not only an accomplished housewife but a musician of more than competent ability. It is true to say that neither Mrs. Mackenzie nor the two daughters had a separate life of their own and evidently needed none, for their father's preoccupation with his researches, which they early appreciated, and 


\section{A. E. Wales and J. Shafar}

the increasing number of visitors which followed from it, gave them a rich variety of experiences even within the limits of a regulated pattern of life in a north country town. Mackenzie was happiest in the centre of his family, and separation from his wife even for a short time was always a trial to him. His times were theirs; his wishes were obeyed without question; when he returned from any enforced absence, both he and his family rejoiced that they were together again.

Towards Dr. Briggs, the senior partner, there is no doubt whatever that Mackenzie's attitude was that of a student to his master. Mackenzie envied Dr. Briggs his skill in diagnosis and prognosis and it was the determination to unravel the secret of such a skill amounting almost to genius, which first set Mackenzie on the path to fame. As a man Mackenzie was of a completely different stamp from Dr. Briggs, as McNair Wilson shows so clearly in his story of Mackenzie's first years as a resident in Dr. Briggs' house, which was ruled over by Miss Briggs, the doctor's sister. But throughout the long association, the admiration and esteem felt by the younger man for the skilled practitioner removed from the relationship any danger of friction which could arise from criticism of older methods of treatment by a younger and more up-to-date colleague. Dr. Briggs' skill was a challenge to Mackenzie's medical education; in meeting it with characteristic Scottish determination and an intellectual honesty sharpened by the scientific nature of an Edinburgh medical education, Mackenzie lived to place medicine in his debt.

His relations with Dr. John Brown, the other partner and with Mrs. Brown, his partner's wife, were quite different. With Dr. Brown the relationship was the reverse of that with Dr. Briggs. Here it was Dr. Brown who idolized his younger colleague; the bonds of friendship forged in the Medical School and Edinburgh Royal Infirmary grew stronger during the years of the Burnley partnership and in Dr. Brown, Mackenzie had a friend who not only urged him along his chosen path of research but encouraged him to make his findings and views known to ever wider audiences. He it was for example, who prompted him to make his visit to Canada and who, if he did not help financially, kept the practice running until Mackenzie's return. He was always ready to discuss and help and encourage during those periods of depression which come to all workers in a new field of knowledge, and he was the very man to act in this manner, for he could talk the same language as Mackenzie and discuss the complicated tracings from the polygraph in a way impossible for Dr. Briggs. It is significant that Mackenzie dedicated his book The Study of the Pulse to 'my old friend Dr. John Brown'.

Mrs. Brown's influence on Mackenzie was just as profound in another sphere. She was one of those women whom the Victorian age nurtured in large numbers who devoted themselves, without ever losing their skill and influence as wives and mothers, to the alleviation of the sufferings of those less fortunate than themselves. She was universally loved and admired for her social work amongst the lowest members and outcasts of society and it can be appreciated that the conditions in Burnley were such as to give her plenty of scope for the exercise of her benevolence and practical help. There is no doubt that as Mackenzie penetrated deeper into the lives and homes of the poorest families in the town, he increasingly appreciated the poverty which existed in the Industrial North and the fear which lay behind questions which his 


\section{Sir James Mackenzie: The Burnley Years}

poorer patients asked, such as 'What will happen to me?' 'When can I get back to work?' His answers to these questions were of critical moment when the only means of livelihood was backbreaking work in mine, mill or foundry, for lack of work meant the Poor Law Institution or starvation. In Mrs. Brown, Mackenzie found someone who was also aware of such things at first hand and one suspects that much of the raw incident which is contained in his novel is the result of discussions with her, for he lived with the Browns for seven years before his marriage. It may be that through Mrs. Brown, Mackenzie first came to appreciate these sturdy, independent, working people.

Towards the end of the century, the following was a typical day in Mackenzie's life. He invariably rose at $6 \mathrm{a} . \mathrm{m}$. and leaving the rest of the family in bed, wrote undisturbed in his study until 8 a.m., completing his case notes, or adding to his increasing list of case histories or writing up the conclusions he had reached during the previous evening's concentrated attention to his tracings. During this period of the day he also wrote the manuscript of his first book-the Study of the Pulse which was published in 1902. How much mental and nervous effort that book cost him can be judged from an extract from the preface:

A second reason is the fact that this volume has been written amid the distractions of the life of a busy general practitioner. I have seldom been able to give an uninterrupted hour's study to the subject. While working out some argument interruptions have often been fatal to its completion, as it has been days and even weeks before I have been able to resume it. While the working out of these problems has been a source of interest and of pleasure, the labour of writing them out has been a weariness to the flesh. This I do not offer as an excuse, but as an explanation.

He also had had articles published in the Journal of Pathology and Bacteriology, the Lancet, the Caledonian Medical Journal, the British Medical Journal, the Edinburgh Medical Journal, and elsewhere, on the pulse, on various aspects of pain and on symptomatology, but this, his first book, and to many one of the classics of medicine, was a heroic attempt to explain his methods, findings and teaching by providing the members of the profession with carefully set out experimental data.

From 9 a.m. to 10 a.m., he attended his morning surgery and then went on his morning rounds in his Victoria. His coachman was Ralph Lofthouse, who never left his service even when the Victoria gave place to the first motor car to be seen in the town. When she was older, his daughter Dorothy frequently accompanied her father and she describes how, during his rounds, her father rarely spoke. He went into every part of the town, and into every kind of house, with the same confident assurance. He walked straight into the house and always offered a kindly but sometimes blunt greeting which generally drew forth an equally terse Lancashire reply. At this period of his life he was trusted and loved because of his universal habit of taking pains to explain his methods to his patients and giving reasons for his diagnosis. All classes of patients sensed his authority and admired his achievements. Coming out of each house, his daughter remembers only how pensive he seemed, as if he were concentrating his whole attention on to the features of the case he had just left. That evening, he would unlock that store of memory, and then in the quiet of his study the following morning, add to his case records. 


\section{A. E. Wales and J. Shafar}

His lunch was on the table at 1 p.m. precisely and he was very rarely late. He ate quickly and never seemed to suffer from indigestion. Then followed a glance at the Manchester Guardian, and a nap until 2 p.m.

On two afternoons in the week he played golf with his friends the Grimshaws at Hapton, but on the others, he ran a special surgery, to which he invited local medical men and those who were staying with him as guests and at these times he demonstrated his methods on selected patients and held group discussions. On such occasions, Mackenzie shone as a leader. Before a large and unsympathetic audience, he was often a failure as a lecturer attempting to convince the members against their will, but in the centre of an intimate group, with the cross fire of question and answer, he was unrivalled, and Osler, Wenckebach, Graham Steell, Pratt, Ross, Cushny and others who enjoyed his hospitality at Bank Parade saw and marvelled how this one hard-worked general practitioner could fuse so successfully with the enthusiastic dedicated research worker. When these men left Burnley, they each acclaimed him as one of the great British physicians. On Sunday afternoons, Mackenzie usually ran another special clinic on the same lines, to which again he invited guests and patients.

After his clinics, Mackenzie made his afternoon round to return for his evening meal at $6.30 \mathrm{p} . \mathrm{m}$. precisely. Unless he and his wife were visiting friends for a social evening or for bridge, a game of which Dr. and Mrs. Brown were very fond and Mackenzie an expert, or he himself was dropping in on one of his friends, or into the club for a game of chess or billiards, at each of which he was a skilled player, the remainder of the evening until 11 p.m. was spent with his family in the drawing room. For those three or four hours while his wife performed at the piano, and his two daughters played around his feet, Mackenzie sat in his winged chair by the fire in the deepest thought. This faculty he possessed of being able to withdraw completely from his surroundings and to concentrate his whole attention on some problem impressed not only his family but all who knew him. He would take out his tracings and study them in conjunction with the details of the cases he had seen that day. He made a few immediate notes the full details being reserved for his work in his study next morning.

Not only did Mackenzie exert great influence on his medical colleagues when he met them in small groups, but in a similar way he had the power to attract great loyalty and devotion from the individual. Dr. Brown felt that attraction and responded to it, but it became even more noticeable in his relationship with those who served him. His coachman-chauffeur never left his service, and the same devoted service was rendered to him by his dispenser Robert Holden, and by Mr. Shaw the instrument maker of Padiham.

Robert Holden was first employed as dispenser to the practice but gradually became increasingly attached to Mackenzie. His life centred around Mackenzie's surgery, where he rolled the pills, prepared the plasters and compounded the medicines, fastening the wrappings with neat precision with a blob of sealing wax. In addition to being dispenser, he became the doctor's personal assistant in many of his experiments. When Mackenzie wished to experiment on the pulse beats of a hen, it was Holden who produced one and assisted in obtaining the traces. Holden was always on duty during surgery hours even on Christmas Day, and on Saturday afternoons, 


\section{Sir James Mackenzie: The Burnley Years}

he it was who went around the alleys and courtyards of down-town Burnley to collect the doctor's debts. It is reliably reported that on occasions he was not above giving the patients in the surgery the benefit of his advice, and sometimes a bottle of medicine. It is safe to say that none got through to Mackenzie but by permission of dispenser Holden. Nevertheless, Mackenzie held Robert Holden and his family in the highest esteem.

Mr. Shaw of Padiham made Mackenzie's first ink polygraph to the latter's instructions. Mackenzie knew what he wished his instrument to do and he outlined these requirements leaving the rest to Shaw. In this man, large-featured, large-bodied and broad-fingered, Mackenzie discovered a real Lancashire character with a wonderful brain and an outstanding flair not only for designing and making delicate mechanisms, but also for assembling such mechanisms into working models. Shaw was much more than the illiterate watchmaker as he is sometimes described. He was one of those mechanical geniuses whom Lancashire has often produced among the working class and to whom the industrial north owes some of its outstanding mechanical inventions. Shaw became a frequent and welcome visitor to Bank Parade and served Mackenzie with great devotion.

Mention has been made above of Mackenzie's co-operation with Ernest Evans, the renowned Head of the Natural Science Department of the Technical Institute, in Saturday afternoon dissections of animal hearts in the Institute laboratories, but an even more intimate friend was John A. Ashworth who was born in Burnley and eventually became Professor of Zoology at Edinburgh and was subsequently elected a Fellow of the Royal Society. He too was a frequent visitor to Bank Parade and it was he who introduced Mackenzie to the wider aspects of animal cardiology.

Towards the end of the Burnley period, Mackenzie gradually took over the running of the practice when Dr. Briggs died and Dr. Brown retired. In 1898 the new junior partners, Drs. Crump and Watson relieved him of night duty which allowed him more time for research. More and more he was consulted by the leading families of Burnley. He played golf with the members of the Grimshaw family, and paid social visits to the homes of Sir John Thursby, the Kay-Shuttleworths of Gawthorpe, the Drews, the Spencers, the Collinges, the Hargreaves and the Tunstalls of Nelson. These are the family names of the district whose members built up their businesses in textiles, engineering and coal mining by hard work and an uncompromising attitude to all outside authority. Mackenzie's obvious skill appealed to their own characteristic forthrightness and success, and their friendship was based on mutual respect and in many cases on a foundation of deep affection. Members of these families provided Mackenzie with many examples for his case books.

Mackenzie was not a religious man in the accepted sense of the term. He had lapsed from the strict presbyterianism of his forebears, but evidently he retained some of their prejudices for he hated the sound of church bells! He found his religion in his devotion to his profession and in the love of his family. He entertained his own, and his wife's parents each year and holidayed with his family in Scotland. The family in the later years enjoyed a continental holiday. When he went to London for meetings, he stayed with his brother, the lawyer who later became Lord Amulree; the latter was evidently a much more precise person with a much more regimented home life. From his 


\section{A. E. Wales and J. Shafar}

attendance at meetings in Manchester, Liverpool or London, Mackenzie would return home sick at heart at the frigid reception accorded to his demonstrations and theories, and especially from the jealousies he encountered amongst the physicians of Manchester and Liverpool. Only Graham Steell of Manchester seemed to have recognized his greatness and it is recorded that for some time, Steell allowed Mackenzie the use of beds in the Manchester Royal Infirmary.

What was it which caused Mackenzie at 53 years of age to pull up his roots in Burnley and move to London in 1907? This decision may not have been as sudden as has been supposed. It is now known that as Mackenzie was beginning to see the fruits of his work and an increasing interest in the results of his clinical teaching on heart conditions by the profession, he became convinced that his work could best be done as a leader of small groups of graduate and post-graduate students within a hospital. One sees the hand of Graham Steell in Mackenzie's contemplated decision to leave general practice and join the staff of the Manchester Royal Infirmary. It was Dr. Brown who dissuaded him and it seems very probable that the result of this change of mind led to the preparation and publication of The Study of the Pulse, which would allow him to present the results of his clinical researches in such a form that his medical colleagues could follow and incorporate them into their practices. It was possibly the comparative failure of this book to convince the profession of the correctness of his views that led him to leave Burnley in 1907 and go to London in an attempt to convince the leaders of medicine in the very centre of the medical world of the radical change necessary in the treatment of abnormal cardiac conditions which his teaching demanded. Osler may have had much influence in the final decision to move to London. Whatever the background to it, future events proved the correctness of what appeared at the time to be a drastically unwise step.

We cannot do better than to end this paper with a quotation from the article by John Cowan-in the first number of the first volume of the British Heart Journal, 'Some Notes on the Cardiac Club'-for this expresses in the best terms the importance of Mackenzie's life and his contribution to medicine and cardiology.

It is difficult to convey to the Georgian a proper impression of the attitude of the late Victorians to heart disease. Laennec's discovery of auscultation dominated the succeeding 50 years and towards the end of the century the characteristic sounds of the various valvular lesions had been fully elucidated. For a time medicine stagnated. Those of us who were residents in medical wards viewed the outlook with dismay for the progress of surgery at that time under the influence of Lister's work was phenomenal, but better times were at hand. The physiological laboratories were at work under Gaskell and others; the bacteriologists were turning their attention to medical subjects. The tubercle bacillus was discovered by Koch, X-rays showed the contents of the Thorax, the sphygmomanometer was adapted for clinical use and the polygraph and later the electro-cardiagraph added their quota to the general store.

But although new methods of investigation became available, a personal influence was needed to speed up the work and James Mackenzie became the centre of the picture.

He had many facets. A tall burly man with all the directness of the North, he seemed at first sight rather dictatorial and overbearing but his transparent goodwill, his unselfishness and his humility soon made manifest that it was merely his intolerance of sham and his search for truth ... Before long he had attracted to himself many men who were interested in the problems of heart disease and had himself suggested to some of our members that a small club should be formed for meetings and discussions. Thus, the Cardiac Club was conceived in Burnley.

We wish to express our gratitude to Lord Platt, for helpful advice. 